\title{
Feed intake of selected vegetables and fruits by coconut lorikeet (Trichoglossus haematodus) in a colony system
}

\author{
SITI NURAMALIATI PRIJONO ${ }^{\natural}$, RINI RACHMATIKA, SINTA MAHARANI \\ Research Centre for Biology, National Research and Innovation Agency. Jl. Raya Jakarta-Bogor Km 46, Cibinong, Bogor 16611, West Java, Indonesia. \\ Tel.: +62-21-8765056, "email: sitiprijono58@ gmail.com
}

Manuscript received: 20 September 2021. Revision accepted: 16 October 2021.

\begin{abstract}
Prijono SN,Rachmatika R, Maharani S. 2021. Feed intake of selected vegetables and fruits by coconut lorikeet (Trichoglossus haematodus) in a colony system. Biodiversitas 22: 4818-4828. Coconut lorikeet (Trichoglossus haematodus (Linnaeus 1771)) is nectarivorous bird. An imbalanced diet is a common problem with lorikeet were kept in captivity. The research method was completely randomized design arranged in a factorial with two factors. The first factor consisted of five types of vegetables or five types of fruits while the second factor consisted of five height levels of feed cup placement $(30 \mathrm{~cm}, 60 \mathrm{~cm}, 90 \mathrm{~cm}, 120 \mathrm{~cm}$ and, $150 \mathrm{~cm}$ from the roof). This study aimed to get information on the feed intake of selected vegetables and fruits that have high attractiveness to meet nutrient requirements and balanced diet for coconut lorikeets kept in a colony aviary. The feed intake of vegetable soybean (26.68 g) was higher than yardlong bean $(21.63 \mathrm{~g})$, green cabbage $(19.12 \mathrm{~g})$, red cabbage $(16.24 \mathrm{~g})$, and broccoli $(14.27 \mathrm{~g})$, while the feed intake of plum $(14.15 \mathrm{~g})$ was higher than apple $(12.31 \mathrm{~g})$, pomegranate $(10.88 \mathrm{~g})$, papaya $(10.55 \mathrm{~g})$ and guava $(9.82 \mathrm{~g})$. Vegetable and fruit intake by six coconut lorikeets in a colony system were $20.80 \%$ of the daily diet, and the siwalan sugar solution was $79.20 \%$ of the daily diet. It was suggested that the coconut lorikeets should be fed more vegetables than fruits. A good quality, varied and balanced diet will make the coconut lorikeets healthy and it will support future conservation effort.
\end{abstract}

Keywords: Attractiveness, captivity, feed placement, nutrition, psittacine

\section{INTRODUCTION}

Coconut lorikeet (Trichoglossus haematodus (Linnaeus 1771)) is a species of parrot in the family Psittaculidae (Order: Psittaciformes), weighing about 130-134 g (Cabana and Lee 2019). This bird is has been included as a Protected Bird in Indonesia since December 2018. According to the International Union for Conservation of Nature (IUCN) Red list status, this species was evaluated in 2018 as of least concern (BirdLife International 2018) and also included in the list of Convention on International Trade in Endangered Species of Wild Fauna and Flora (CITES) Appendix II (CITES 2017). Coconut lorikeet was endangered due to habitat destruction and heavily traded. In the wild, the lorikeet primarily feeds on nectar as a source of carbohydrate and pollen as a source of protein (Gellis 2011). In captivity, an imbalanced diet is a common problem with lorikeet and is a relatively common illness even causes death. A balanced diet for lorikeet can be achieved if a nectar based diet are supplemented with a variety of vegetables and fruits (Klarich 2012). Vegetables and fruits are considered in dietary guidance because of their high concentrations of dietary fiber, vitamins, minerals, especially electrolytes; and more recently phytochemicals, especially antioxidants (Slavin and Llyod 2012). Since the highest expenses for keeping birds in captivity were the bird's diet, therefore it is important to identify the vegetables and fruits with the most attract the coconut lorikeets to prevent a lot of feed wasted and reduce the feed cost. Vegetables and fruits were providing macronutrients (protein, fat, fiber, carbohydrate, and water), and micronutrients (vitamins and minerals) that attract birds to eat are very important to be used as a basic ingredient in the preparation of coconut lorikeets diet. Lorikeets are arboreal and often seen feeding high up in the canopy of trees. They rarely come to the ground to feed (Klarich 2012), therefore the feed should be placed in the highest level in the aviary.

The coconut lorikeets take much longer to adapt to captivity. Feeding lorikeets in captivity is one of the most challenging aspects of their care. The specific nutritional requirements of coconut lorikeet in captivity for maintenance, growth, and reproduction are not known and the dietary information is mostly incomplete. It can be hard to visualize the recommended daily amounts of macronutrients and micronutrients in the lorikeets' diet. One way to do this is to ensure that coconut lorikeets get a variety of vegetables and fruits in their diet. The effort to feed the coconut lorikeet with proper diets to meet the nutritional requirements and a balanced diet will support conservation efforts for the birds. Bird conservation efforts include reducing mortality rates, improving the health and reproduction of birds in captivity, thereby reducing pressure to collect more individuals from the wild (BirnieGauvin et al. 2017).

The aim of this study was to get information on the feed intake of selected vegetables and fruits that have high attractiveness to meet nutrient requirements and balanced diet for coconut lorikeets were kept in colony aviary. The results of this study will give suggestions for the most 
appropriate vegetables and fruits as supplemented diet for coconut lorikeet to maintain balanced nutrition and the level of placement of feed cups in colony aviary.

\section{MATERIAL AND METHODS}

\section{Birds care and housing}

Six wild coconut lorikeets from Ambon were lent to Research Center for Biology by Mr. Suwita (CV. Pasundan) in May 2018, for which sex was not yet ascertained because the birds were sexually monomorphic in appearance, although there was considerable colour variation. It was difficult to distinguish female and male if only from the plumage colour. From May 2018 to December 2019, the coconut lorikeets were kept in cages measuring $90 \times 55 \times 60 \mathrm{~cm}$ for two birds in each cage. The birds used in this study were kept in a colony aviary measuring $3.90 \times 3.5 \times 2.9 \mathrm{~m}$ since January 2020 and contained natural perches. The colony aviary used in this study was located in the Research Center for Biology, National Research and Innovation Agency (BRIN), Cibinong, Indonesia. In the adaptation period the birds were kept in the colony aviary for six months (January June 2020), the birds were introduced to various types of feeds.

The study on attractiveness and feed intake for different types of vegetables and fruits were carried out in July to September 2020. In this study, the birds were fed with siwalan sugar solution-based diet as the main diet. The birds were also trial fed with supplemented diet such as fresh vegetables and fruits. In captivity, the birds have to navigate perches to reach their feed in feed cups. Therefore, we put natural perches in front of feed cups. The feed cups were used in this study have a diameter of $10 \mathrm{~cm}$, a height of $7 \mathrm{~cm}$ which has a hook, therefore this cup can be attached to one side of the aviary wall which made of iron trellis. The vegetables and fruits were thoroughly washed to remove unwanted material and dirt, then sliced into bite-sized pieces $(0.5 \times 0.5 \times 3 \mathrm{~cm}$ or $1.0 \times$ $1.0 \times 1.0)$. We offer vegetables in a sliced form, except yardlong bean in $5 \mathrm{~cm}$ cutting, cauliflower, and broccoli in pieces forms into bite-sized pieces that the birds can pick up with their feet to gnaw on. Snap pea was offered raw without slicing or cutting. Vegetable soybeans were boiled with the bean still in the pods to ensure that all the nutrients remain intact and become tender after boiling. We offer fruits in a sliced form. Apple, mango, orange, banana, and papaya were peeled before sliced. According to Pem and Jeewon (2015), the seed pits of apples were removed before offering to the bird in order to avoid the small amount of cyanide in them. The edible part of the pomegranate that offering to the birds is aril and seeds. The small fruits such as buni and kersen were offered the whole fruit. In this study, we carried out two experiments. In experiment 1 , the birds were offered 15 types of vegetables (broccoli, cauliflower, celery, green cabbage, leaf lettuce, mustard greens, napa cabbage, pak choi, parsley, red cabbage, snap pea, spinach, vegetable soybean, water

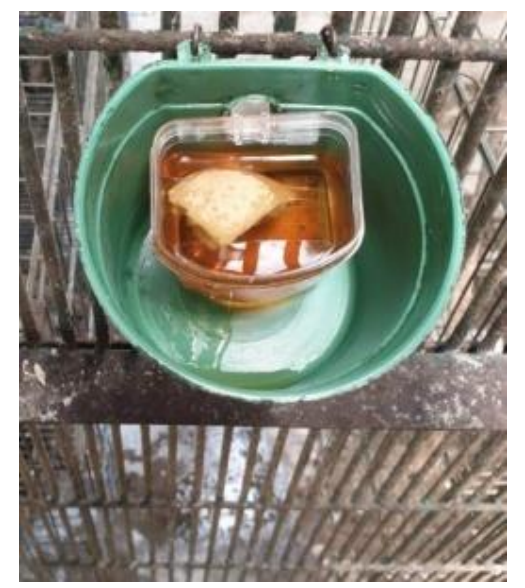

Figure 1. Siwalan sugar solution added commercial baby biscuit in a cup

spinach, yardlong bean) and 15 types of fruits (apple, blackberry, buni, cherry, guava, kersen, ladyfinger bananas, mandarin orange, mango, papaya, plum, pomegranate, strawberry, tamarillo, watermelon), while in experiment 2 , the birds were offered five types of selected vegetables and five types of selected fruits which were the most attractive by the birds in experiment 1 . In each day's experiments, the coconut lorikeets were also offered five cups siwalan sugar solution (each cup contains 70 grams include three gram commercial baby biscuits) as a main diet, a source of carbohydrate, and protein for the coconut lorikeets. The feed cup that was used for the siwalan sugar solution has a diameter of $5 \mathrm{~cm}$, the height of $4 \mathrm{~cm}$ and then this cup was put in the bigger cup (diameter of $10 \mathrm{~cm}$, height of $7 \mathrm{~cm}$ ) which has a hook (Figure 1). These cups were attached to one side of the aviary wall which is made of iron trellis and distributed at a height level of $30 \mathrm{~cm}$ from the roof. Water for drinking was provided ad libitum. The coconut lorikeets enjoy bathing, therefore, the water in the swallowing bowl was also provided in the aviary.

\section{Experiment 1}

The birds were fed 15 types of vegetables (broccoli and cauliflower, celery and parsley in the pieces form; green cabbage, leaf lettuce, mustard greens, napa cabbage, pak choi, red cabbage, spinach, and water spinach in the slices form; snap pea (whole snap pea), vegetable soybean (boiled, the bean still in the pod), yardlong bean $(5 \mathrm{~cm}$ cutting)) and 15 types of fruits (buni, cherry, kersen (whole fruit); apple, blackberry, guava, ladyfinger bananas, mandarin orange, mango, papaya, plum, strawberry, tamarillo, watermelon (in the slices form), pomegranate (seeds and aril). These vegetables and fruits in the feed cups were placed on one side of the aviary with the feed cups placed at the same height level at $30 \mathrm{~cm}$ from the roof. Each day the coconut lorikeets were offered a different type of vegetables and fruits in ten cups. The scan sampling technique was applied to observing feeding behaviour on the attractiveness the coconut lorikeets on the various types of vegetables and fruits (Martin and Bateson 1986). We observed each vegetable and each fruit that attracts the birds in one hour each day for three days. If five to six 
birds take the vegetables and fruits across the one hour we stated that the attractiveness was high. If three to four birds take the vegetables or fruits across the one hour, we stated that the attractiveness was medium. If one to two birds take the type of vegetables or fruits across the one hour, we stated low attractiveness. If no one bird takes the type of vegetables or fruits across the one hour, we stated that was unattractive.

\section{Experiment 2}

The birds were offered five selected types of vegetables and five selected fruits that have high attractiveness by the birds in experiment 1 . For each selected vegetables and fruits were placed in a feed cup (diameter of $5 \mathrm{~cm}$, height of $4 \mathrm{~cm})$ at five height levels of feed cup placement $(30 \mathrm{~cm}$, $60 \mathrm{~cm}, 90 \mathrm{~cm}, 120 \mathrm{~cm}$ and, $150 \mathrm{~cm}$ from the roof) (Figure 2.A). Each cup contains 40 grams of each type of vegetable or fruit (Figure 2.B-C). The birds were offered five selected types of vegetables or fruits in five levels of feeding cup placement at different heights for five days in five replications. Each experiment was run for 24 hours (from 08:00 a.m. to 08:00 a.m on the next day).

Each feed cup containing the vegetable or fruits was weighed before being given to the birds in the morning, and the amount of the vegetables or fruits left in the feed cup and that fell on the floor were weighed in the next morning.The feed intake (measured as wet mass) for each type of vegetables and fruits in each height level of feed cup placement was determined. These were quantified by subtracting the mass of the feed left over from the amount given. Evaporative moisture loss from the uneaten food was estimated using controls.

\section{Data analysis}

Data obtained were analyzed using a two-way Analysis of Variance (ANOVA) followed by a Duncan post hoc test to assess the significant differences among experimental mean values $(\mathrm{P}<0.05)$ and the Kolmogorov-Smirnov test for normality of the distribution. All statistical analysis was performed using SPSS software version 23.0. The research method was completely randomized design arranged in a factorial with two factors. The first factor consisted of five types of vegetables or five types of fruits while the second factor consisted of five height levels of feed cup placement $(30 \mathrm{~cm}, 60 \mathrm{~cm}, 90 \mathrm{~cm}, 120 \mathrm{~cm}$ and, 150 $\mathrm{cm}$ from the roof).

\section{Ethical clearance}

Ethical clearance for this study has been approved by a research ethic clearance committee of the Indonesian Institute of Sciences No. 2/klirens/VII/2020. During the trial, all birds were monitored every day to ensure their wellbeing.



A

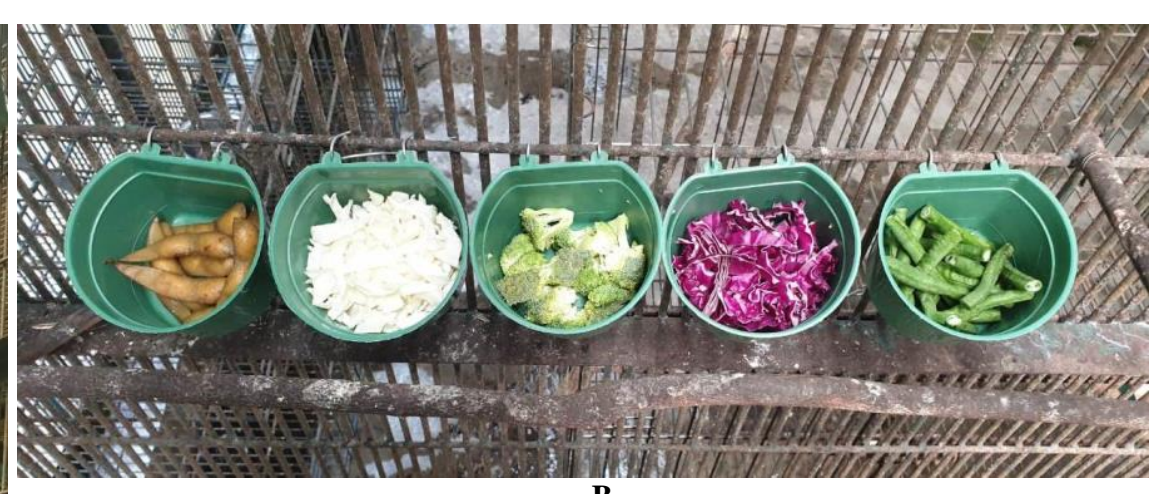

B



C

Figure 2.A. Feed cups were placed in five different levels of feed cup placement. B. Five cups containing five selected vegetables (left to right): vegetable soybean, green cabbage, broccoli, red cabbage, yardlong bean; C. Five cups containing five selected fruits: guava, apple, papaya, plum, pomegranate 


\section{RESULTS AND DISCUSSION}

\section{The attractiveness of vegetables and fruits}

Temperature and humidity during the experiments varied from $21^{\circ} \mathrm{C}$ to $32^{\circ} \mathrm{C}$ and $\mathrm{RH}=45-95 \%$. Based on our experience of watching the feeding behavior of the coconut lorikeet in captivity, there is a way to test vegetables and fruits whether the bird is attracted or not. If we offered one type of vegetable or one type of fruit that attracts the coconut lorikeets, then the birds will soon gather in flocks approaching the feeding place and take the vegetable or fruit in a cup (Figure 3). The results of the experiment 1 on the observation of attractiveness of various types of vegetables and fruits can be seen in Table 1. The results of this study showed that there were five vegetables (green cabbage, red cabbage, yardlong bean, vegetable soybean, broccoli) and five fruits (apple, guava, papaya, pomegranate, plum) were having a high rank of attractiveness. Three types of vegetables (napa cabbage, lettuce, pak choi) and four types of fruit (mango, mandarin orange, ladyfinger bananas, watermelon) have a medium rank of attractiveness. Four types of vegetables (snap pea, cauliflower, mustard green, water spinach) and two types of fruits (strawberry and cherry) have a low rank of attractiveness. Three types of vegetables (spinach, celery, and parsley) and four types of fruits (kersen, buni, blackberry, and tamarillo) were unattractive to the birds.

\section{Feed intake of vegetables}

The feed intake of the vegetables based on feed cup placement in different height levels can be seen in Table 2. This study showed that the feed intake of vegetables with the highest and the second level of feed cup placement was significantly higher than the feed cup placed at the lower level. The feed intake of vegetable soybean at the first, third, and fourth levels of feed cup placement was significantly higher than red cabbage, yardlong bean, and broccoli. In the second level of feed cup placement, the feed intake of green cabbage was significantly higher than the red cabbage, yardlong bean, and broccoli but not significantly different with vegetable soybean.

The overall daily intake for six coconut lorikeets was the sum of feed intake from the first to the fifth level of feed cup placement. The daily intake for vegetable soybean, yardlong bean, green cabbage, red cabbage, and broccoli for six coconut lorikeets in colony aviary was $26.68 \mathrm{~g}, 21.63 \mathrm{~g}, 19.12 \mathrm{~g}, 16.24 \mathrm{~g}$, and $14.27 \mathrm{~g}$ respectively (Table 3). The result showed that the coconut lorikeet favoured the vegetable soybean compared to other vegetables. The coconut lorikeets were so excited when we gave them boiled vegetable soybean, they quickly came to the feed cup containing vegetable soybean. They picked up the vegetable soybean with their beak, then holding the vegetable soybean with one of their feet, and then they picked the bean out of the pod with their beak to crush and eat (Figure 4).

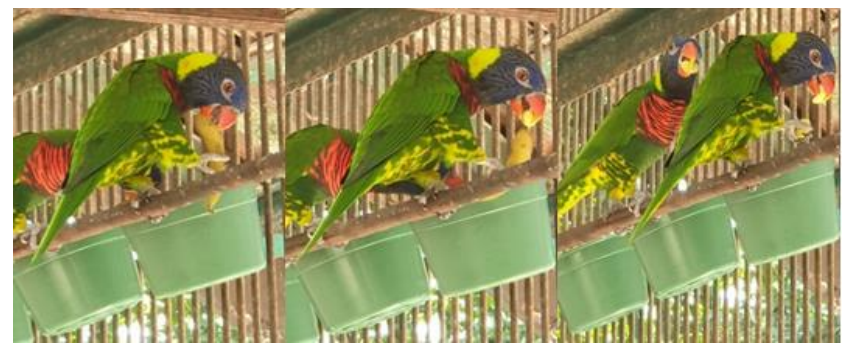

Figure 4. The coconut lorikeets were eating vegetable soybean in the first feed cup placement

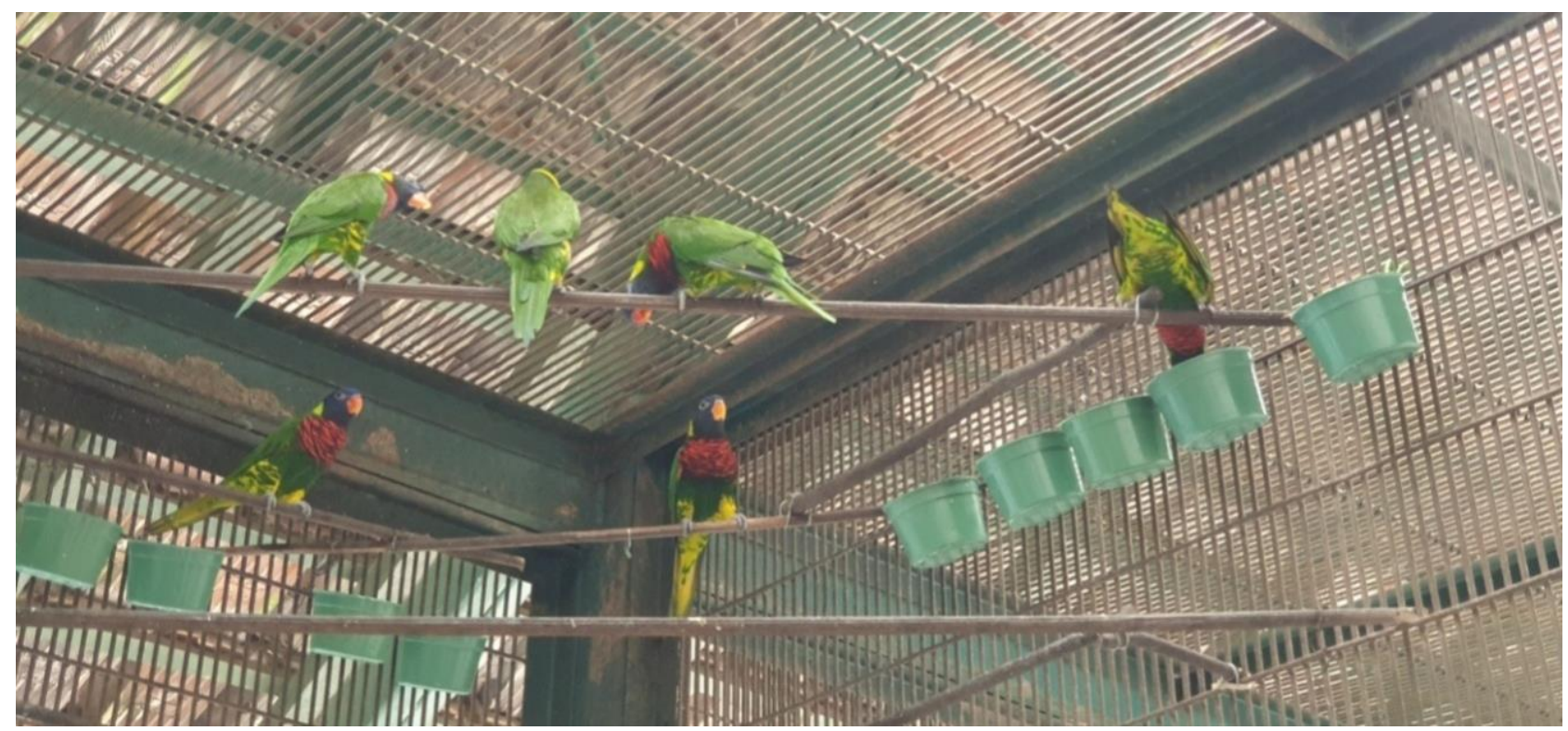

Figure 3. The coconut lorikeets gather in flocks since they attracted to the vegetables or fruits in the feed cups 
Table 1. The attractiveness of vegetables and fruits for coconut lorikeets

\begin{tabular}{|c|c|c|c|}
\hline Type of vegetables \& fruits & Scientific name & $\begin{array}{l}\text { No. of birds take } \\
\text { vegetables/ fruits }\end{array}$ & $\begin{array}{c}\text { Attracti- } \\
\text { veness }\end{array}$ \\
\hline \multicolumn{4}{|l|}{ Vegetables } \\
\hline Broccoli & Brassica oleracea var. italic & 6 & High \\
\hline Green cabbage & Brassica oleracea var. capitata & 6 & High \\
\hline Vegetable soybean (edamame) & Glycine $\max (\mathrm{L})$ Merr. & 6 & High \\
\hline Yardlong bean/asparagus bean & Vigna ungulate subsp. sesquipedalis & 6 & High \\
\hline Red/purple cabbage & Brassica oleracea var. capitata & 5 & High \\
\hline Pak choi & Brassica rapa var. chinensis & 4 & Medium \\
\hline Leaf lettuce & Lactuca sativa $\mathrm{L}$. & 3 & Medium \\
\hline Napa cabbage & Brassica rapa subsp. pekinensis & 3 & Medium \\
\hline Snap pea & Pisum sativum $\mathrm{L}$ & 2 & Low \\
\hline Cauliflower & Brassica oleracea var. botrytis & 1 & Low \\
\hline Mustard greens & Brasisca rapa var. parachinensis & 1 & Low \\
\hline Water spinach & Ipomoea aquatic Forssk & 1 & Low \\
\hline Celery & Apium graveolens $\mathrm{L}$. & 0 & Unattractive \\
\hline Spinach & Spinacia oleracea $\mathrm{L}$ & 0 & Unattractive \\
\hline Parsley & Petroselinum crispum (Mill) & 0 & Unattractive \\
\hline \multicolumn{4}{|l|}{ Fruits } \\
\hline Apple & Malus domestica Borkh & 6 & High \\
\hline Papaya & Carica papaya $\mathrm{L}$ & 6 & High \\
\hline Plum & Prunus domestica $\mathrm{L}$ & 6 & High \\
\hline Guava & Psidium guajava $\mathrm{L}$ & 5 & High \\
\hline Pomegranate & Punica granatum $\mathrm{L}$ & 5 & High \\
\hline Ladyfinger bananas/sugar bananas & Musa acuminata Colla & 4 & Medium \\
\hline Mandarin orange & Citrus reticulata $\mathrm{L}$ & 4 & Medium \\
\hline Mango & Mangifera indica $\mathrm{L}$ & 4 & Medium \\
\hline Watermelon & Citrullus lanatus (Thunb) Matsum \& Nakai & 4 & Medium \\
\hline Strawberry & Fragaria $x$ ananassa & 2 & Low \\
\hline Cherry & Prunus avium L & 2 & Low \\
\hline Blackberry & Rubus fruticosus $\mathrm{L}$ & 0 & Unattractive \\
\hline Buni & Antidesma bunius L. Spreng & 0 & Unattractive \\
\hline Tamarillo & Solanum betaceum (Cav) & 0 & Unattractive \\
\hline Kersen & Muntingia calabura $\mathrm{L}$ & 0 & Unattractive \\
\hline
\end{tabular}

Table 2. Feed intake of vegetables (gram) for six coconut lorikeets in different levels of feed cup placement in colony aviary

\begin{tabular}{|c|c|c|c|c|c|}
\hline \multirow{2}{*}{ Vegetables } & \multicolumn{5}{|c|}{ Height Level of feed cup placement from the roof } \\
\hline & $30 \mathrm{~cm}(1)$ & $60 \mathrm{~cm}(2)$ & $90 \mathrm{~cm}(3)$ & $120 \mathrm{~cm} \mathrm{(4)}$ & $150 \mathrm{~cm}(5)$ \\
\hline Green Cabbage & $8.27 \pm 2.22^{b}$ & $8.35 \pm 1.93^{\mathrm{b}}$ & $1.95 \pm 0.59^{\mathrm{hi}}$ & $0.55 \pm 0.93^{\mathrm{jk}}$ & $0^{\mathrm{k}}$ \\
\hline Red Cabbage & $7.59 \pm 2.01^{\mathrm{bc}}$ & $6.29 \pm 3.13^{\mathrm{d}}$ & $1.82 \pm 0.61 \mathrm{hi}$ & $0.54 \pm 0.85^{\mathrm{jk}}$ & $0^{\mathrm{k}}$ \\
\hline Vegetable soybean (Edamame) & $10.02 \pm 1.59^{\mathrm{a}}$ & $7.93 \pm 2.22^{b}$ & $4.32 \pm 2.31^{\mathrm{f}}$ & $3.22 \pm 0.68^{g}$ & $1.39 \pm 0.42$ \\
\hline Yardlong Bean & $7.55 \pm 2.84 \mathrm{bc}$ & $6.79 \pm 2.85^{\mathrm{cd}}$ & $3.32 \pm 0.86^{\mathrm{g}}$ & $2.22 \pm 0.53^{i}$ & $1.75 \pm 0.33^{\mathrm{h}}$ \\
\hline Broccoli & $5.36 \pm 1.52^{\mathrm{e}}$ & $4.35 \pm 1.84^{\mathrm{f}}$ & $2.56 \pm 0.78$ gh & $1.58 \pm 0.66^{\text {hij }}$ & $0.42 \pm 0.52$ \\
\hline
\end{tabular}

Note: abcValues with different superscript indicate significantly different result $(\mathrm{P}<0.05)$ based on Duncan Test

Table 3. Daily intake vegetables for six coconut lorikeets in colony aviary

\begin{tabular}{lr}
\hline Vegetables & Feed Intake $(\mathbf{g})$ \\
\hline Green cabbage & $19.12 \pm 3.97$ \\
Red cabbage & $16.24 \pm 3.56$ \\
Vegetable soybean (Edamame) & $26.88 \pm 3.42$ \\
Yardlong bean & $21.63 \pm 3.03$ \\
Broccoli & $14.27 \pm 2.15$ \\
Total feed intake of vegetables & $98.14 \pm 4.41$ \\
\hline
\end{tabular}

Lorikeets are a nectar feeder (nectarivorous), they consume soft and wet food. Being primarily the high moisture of their food, they do not have strength the beak to crack seeds or nuts as other parrots (Gellis 2011), therefore we gave them tender boiled vegetable soybean not raw vegetable soybean with hard bean. The coconut lorikeet favoured a tender bean and the taste of boiled vegetable soybean. Besides the taste, the vegetable soybean is also rich in nutrition compares to green cabbage, red cabbage, yardlong bean, and broccoli. The nutrient content of five vegetables can be seen in Table 4. The nutritive value per $100 \mathrm{~g}$ vegetable soybean contains high in carbohydrate $8.9 \mathrm{~g}$ followed by protein $(12.0 \mathrm{~g})$, fat $(5.0 \mathrm{~g})$, fiber $(5.2 \mathrm{~g})$, and ash (1.2 g). Vegetable soybean is also rich in micronutrients, especially they are rich in vitamins such as folate, niacin (Vitamin B3), riboflavin (Vitamin B2), 
thiamin (Vitamin B1), and minerals such as calcium, copper, iron, magnesium, manganese phosphorus, potassium, and zinc.

The second favoured vegetable for coconut lorikeet was a yardlong bean. The feed intake in the first level of feed cup placement and overall daily feed intake of yardlong bean was lower than soybean vegetable but higher than broccoli. The coconut lorikeet enjoyed eating by holding the yardlong bean with their feet. Composition of nutrition per 100 grams yardlong bean as follows: high in carbohydrate $(8.35 \mathrm{~g})$, protein $(2.8 \mathrm{~g})$, and fiber $(4.0 \mathrm{~g})$, but low in fat $(0.4 \mathrm{~g})$ and ash $(0.8 \mathrm{~g})$. Yardlong bean content of various kinds contain important micro nutrients, such as rich in vitamin A and mineral rich in calsium, magnesium, phosphorus, potassium, and selenium.

The third and fourth favoured vegetables for coconut lorikeet was green cabbage and red cabbage. The feed intake of green cabbage in the second level of feed cup placement was significantly higher than red cabbage, yardlong bean, and broccoli but not significantly different with vegetable soybean. Overall the daily intake of green cabbage was slightly higher than red cabbage. The coconut lorikeet showed a preference for green cabbage than red cabbage. Table 4 showed that green and red cabbage have higher moisture content (92.18 g and $90.39 \mathrm{~g}$ respectively) and higher sugar than other vegetables, but contain low protein, fat, and energy. Green cabbage contained higher levels of folate, pantothenic acid, vitamin $\mathrm{E}$, and vitamin $\mathrm{K}$ than red cabbage, while red cabbage content higher iron, manganese, potassium, and sodium than green cabbage. Red cabbage contained higher vitamin A and B6 than other vegetables.

The fifth favoured vegetable for coconut lorikeet was broccoli. The feed intake of broccoli in the first and second levels of feed cup placement was the lowest comparable to vegetable soybean, green cabbage, red cabbage, and yardlong bean. Overall daily intake of broccoli was the lowest. Instead of the feed intake of broccoli was low, broccoli can provide nutrient which is needed by lorikeet. Broccoli is rich in dietary fiber, minerals, vitamins, and antioxidants that have proven health benefits (Madhu and Kochhar 2014). Fresh broccoli is an exceptionally rich source of vitamin C. Furthermore, broccoli is also rich in pantothenic acid, vitamin $\mathrm{E}$, and $\mathrm{K}$ and contains higher sodium than other vegetables.

Table 4. Nutrient composition vegetables per $100 \mathrm{~g}$

\begin{tabular}{|c|c|c|c|c|c|c|}
\hline \multirow{2}{*}{ Nutrient } & \multirow{2}{*}{ Units } & \multicolumn{5}{|c|}{ Value per 100 grams } \\
\hline & & Green cabbage & Red cabbage & Vegetable Soybean & Yardlong bean & Broccoli \\
\hline \multicolumn{7}{|l|}{ Macronutrients } \\
\hline Water & gram & 92.18 & 90.39 & 72.77 & 87.85 & 89.30 \\
\hline Total Fat & gram & 0.10 & 0.16 & 5.20 & 0.40 & 0.37 \\
\hline Protein & gram & 1.30 & 1.43 & 12.00 & 2.80 & 2.82 \\
\hline Total carbohydrate & gram & 5.80 & 7.37 & 8.91 & 8.35 & 6.64 \\
\hline Energy & kcal & 25.00 & 31.00 & 121.00 & 47.00 & 34.00 \\
\hline Dietary fiber & gram & 2.50 & 2.10 & 5.20 & 4.00 & 2.60 \\
\hline Sugar & gram & 3.20 & 3.83 & 2.18 & 1.88 & 1.70 \\
\hline Ash & gram & 0.64 & 0.64 & 1.21 & 0.58 & 0.87 \\
\hline \multicolumn{7}{|l|}{ Micronutrients } \\
\hline \multicolumn{7}{|l|}{ Vitamin } \\
\hline Folate & $\mathrm{mcg}$ & 43.00 & 18.00 & 311.00 & 62.00 & 63.00 \\
\hline Niacin (Vit B3) & $\mathrm{mg}$ & 0.23 & 0.42 & 0.96 & 0.41 & 0.64 \\
\hline Pantothenic acid & $\mathrm{mg}$ & 0.21 & 0.15 & 0.40 & 0.06 & 0.57 \\
\hline Riboflavin (Vit B2) & $\mathrm{mg}$ & 0.04 & 0.07 & 0.16 & 0.11 & 0.12 \\
\hline Thiamin (Vit B1) & $\mathrm{mg}$ & 0.06 & 0.06 & 0.20 & 0.11 & 0.07 \\
\hline Vitamin A & IU & 98.00 & 1116.00 & 298.00 & 865.00 & 623.00 \\
\hline Vitamin B6 & $\mathrm{mg}$ & 0.12 & 0.21 & 0.10 & 0.02 & 0.18 \\
\hline Vitamin $\mathrm{C}$ & $\mathrm{mg}$ & 36.60 & 57.00 & 6.10 & 18.80 & 89.20 \\
\hline Vitamin E & $\mathrm{mg}$ & 0.15 & 0.11 & 0.68 & 0.00 & 0.78 \\
\hline Vitamin K & $\mathrm{mcg}$ & 76.00 & 38.20 & 26.70 & 41.60 & 101.60 \\
\hline \multicolumn{7}{|l|}{ Minerals } \\
\hline Calcium, $\mathrm{Ca}$ & $\mathrm{mg}$ & 40.00 & 45.00 & 63.00 & 50.00 & 47.00 \\
\hline Copper, $\mathrm{Cu}$ & $\mathrm{mg}$ & 0.02 & 0.02 & 0.35 & 0.05 & 0.05 \\
\hline Iron, $\mathrm{Fe}$ & $\mathrm{mg}$ & 0.47 & 0.80 & 2.27 & 0.47 & 0.73 \\
\hline Magnesium, $\mathrm{Mg}$ & $\mathrm{mg}$ & 12.00 & 16.00 & 64.00 & 44.00 & 21.00 \\
\hline Manganese, Mn & $\mathrm{mg}$ & 0.16 & 0.24 & 1.02 & 0.21 & 0.21 \\
\hline Phosphorus, $\mathrm{P}$ & $\mathrm{mg}$ & 26.00 & 30.00 & 169.00 & 59.00 & 66.00 \\
\hline Potassium, K & $\mathrm{mg}$ & 170.00 & 243.00 & 436.00 & 240.00 & 316.00 \\
\hline Selenium, Se & $\mathrm{mcg}$ & 0.30 & 0.60 & 0.80 & 1.50 & 2.50 \\
\hline Sodium, $\mathrm{Na}$ & $\mathrm{mg}$ & 18.00 & 27.00 & 6.00 & 4.00 & 33.00 \\
\hline Zinc, Zn & $\mathrm{mg}$ & 0.18 & 0.22 & 1.37 & 0.37 & 0.41 \\
\hline
\end{tabular}

Note: USDA standard reference 2021 (https://www.nutritionvalue.org) 


\section{Feed intake of fruit}

The feed intake of five selected fruits in each level of feed cup placement can be seen in Table 5. The feed intake of all the fruits was higher in the first level of feed cup placement compared to the lower place such as in the second, third, fourth, and fifth of feed cup placement. Feed intake of all fruits in the third, fourth and fifth levels of feed cup placement were very low. Feed intake of plum in the first level of feed cup placement was significantly higher than papaya, pomegranate, and guava but not significantly different from apple. In the second and third levels of feed cup placement, the feed intake of plum was significantly higher than all selected fruits such as apple, pomegranate, papaya, and guava.

The overall daily intake for plum, apple, pomegranate, papaya, and guava for six coconut lorikeets in colony aviary were $14.15 \mathrm{~g}, 12.31 \mathrm{~g}, 10.88 \mathrm{~g}, 10.55 \mathrm{~g}$, and $9.82 \mathrm{~g}$ respectively (Table 6 ). The results showed that the coconut lorikeet favoured the plum compared to other fruits. The coconut lorikeet eating plum can be seen in Figure 5. The plum is a fleshy simple fruits category drupe fruit or stone fruit type. The plum offered to the birds was the plum which has skin purple-red and the flesh inside plums is yellow with seeds. The coconut lorikeet favoured the plum even though the macronutrient and micronutrient content in the plum is in general lower than pomegranate, guava and papaya but higher than apple (Table 7). The type of fruit which the second favoured for coconut lorikeet was the apple. The feed intake of apple was slightly lower than plum in the first level of feed cup placement but significantly higher than pomegranate, guava, and papaya. In general, the daily feed intake of apple was lower than the plum. Apple content higher sugar than plum, guava, and papaya but lower than pomegranate. It seems that the coconut lorikeet favoured the plum because of their sweet taste, the texture of the flesh is soft and juicy with a delicate flavour. The type of fruits which the third, fourth and fifth favoured by the coconut lorikeet was pomegranate, papaya, and guava. These fruits include in the category as a simple fruit fleshy berry. The taste of these fleshy berry fruits is sweet. In the pomegranate, the edible part is the fleshy layer (aril) around each seed. Feed intake of pomegranate is almost the same as papaya but higher than guava.

The nutritional value of pomegranate, papaya, and guava can be seen in Table 7. Pomegranate rich in calories, dietary fiber, ash, and also vitamin $\mathrm{C}$, vitamin $\mathrm{K}$, and mineral Zinc. Papaya has low calories but rich in vitamin $\mathrm{A}$ and minerals such as calcium and iron. The type of fruit which the last favoured by the coconut lorikeet was guava. Guava was used in this experiment was guava with flesh pink in colour. Ripe guava has a sweet, slightly soft, juicy, and unique flavour. Guava rich in protein compare than the other selected fruits. Guava also rich in vitamins such as folate, niacin, and vitamin $\mathrm{C}$ and rich in minerals such as copper, manganese, phosphorus, and potassium.

\section{Feed intake of siwalan sugar solution}

In the wild, nectar from flowering plants is a sugar-rich food that provides the major energy source for lorikeets and other nectarivorous species (Gellis, 2011). In captivity, coconut lorikeet prefer a sweet diet such as brown sugar/palm sugar solution as an alternative carbohydrate source to substitute nectar (Prijono and Rachmatika 2019; Prijono and Rachmatika 2020). The main diet for coconut lorikeet during this study was siwalan sugar solution (one type of palm sugar) with $20 \%$ concentration. This siwalan sugar solution added with a commercial baby biscuit to increase the protein content in the main diet. The result of this study showed that the coconut lorikeets were kept in a colony aviary consumed $79.20 \%$ of their diet in the form of siwalan sugar solution (593.4 g/6 birds/day) as an alternative source of carbohydrate while vegetables and fruits were $20.80 \%$ (vegetables $=13.10 \%$; fruits $=7.70 \%$ ).

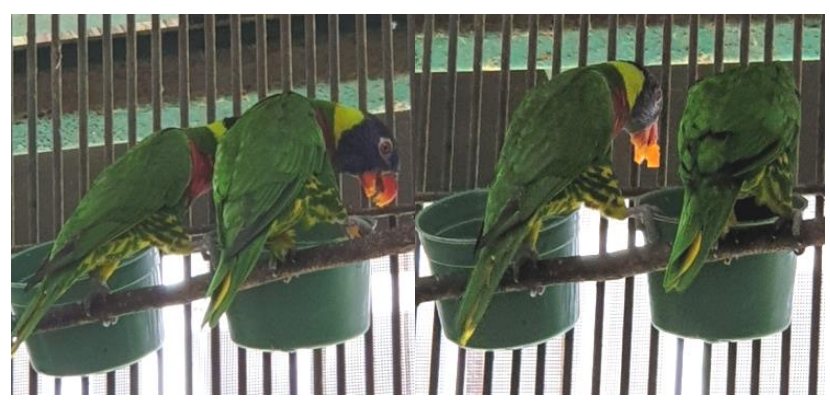

Figure 5. The coconut lorikeets were eating plum

Table 6. Daily feed intake fruits for six coconut lorikeets in colony aviary

\begin{tabular}{lc}
\hline \multicolumn{1}{c}{ Fruits } & Feed intake $(\mathrm{g})$ \\
\hline Apple & $12.31 \pm 2.38$ \\
Pomegranate & $10.88 \pm 2.15$ \\
Guava & $9.82 \pm 1.78$ \\
Papaya & $10.55 \pm 1.93$ \\
Plum & $14.15 \pm 2.46$ \\
Total feed intake of fruits & $57.71 \pm 1.53$ \\
\hline
\end{tabular}

Table 5. Feed Intake of fruits (gram) per day for six coconut lorikeets in different levels of feed cup placement in colony aviary

\begin{tabular}{|c|c|c|c|c|c|}
\hline \multirow{2}{*}{ Fruits } & \multicolumn{5}{|c|}{ Height level of feed cups placement from the roof } \\
\hline & $30 \mathrm{~cm}(1)$ & $60 \mathrm{~cm}(2)$ & $90 \mathrm{~cm}(3)$ & $120 \mathrm{~cm} \mathrm{(4)}$ & $150 \mathrm{~cm}(5)$ \\
\hline Apple & $6.31 \pm 1.19^{a}$ & $3.50 \pm 0.690^{\mathrm{e}}$ & $1.89 \pm 0.65^{\mathrm{g}}$ & $0.53 \pm 0.59^{\mathrm{hi}}$ & $0.08 \pm 0.21^{\mathrm{j}}$ \\
\hline Pomegranate & $5.58 \pm 0.70^{\mathrm{b}}$ & $3.26 \pm 0.96^{\mathrm{e}}$ & $1.70 \pm 0.78^{\mathrm{g}}$ & $0.29 \pm 0.32^{j}$ & $0.05 \pm 0.13^{\mathrm{j}}$ \\
\hline Guava & $4.48 \pm 0.63^{\mathrm{cd}}$ & $3.24 \pm 0.68^{\mathrm{e}}$ & $1.52 \pm 0.94^{\mathrm{g}}$ & $0.45 \pm 0.46^{\mathrm{hij}}$ & $0.13 \pm 0.26^{j}$ \\
\hline Papaya & $4.76 \pm 0.95^{\mathrm{c}}$ & $3.45 \pm 0.83^{\mathrm{e}}$ & $1.95 \pm 0.81^{\mathrm{g}}$ & $0.32 \pm 0.43^{\mathrm{j}}$ & $0.07 \pm 0.18^{\mathrm{j}}$ \\
\hline Plum & $6.54 \pm 1.01^{\mathrm{a}}$ & $4.13 \pm 0.72^{\mathrm{d}}$ & $2.61 \pm 1.02^{f}$ & $0.80 \pm 0.68^{\mathrm{h}}$ & $0.07 \pm 0.21^{\mathrm{j}}$ \\
\hline
\end{tabular}

Note: abcValues with different superscript indicate significantly different result $(\mathrm{P}<0.05)$ based on Duncan Test 
Table 7. Nutrient compositionfruits per $100 \mathrm{~g}$

\begin{tabular}{|c|c|c|c|c|c|c|}
\hline \multirow{2}{*}{ Nutrient } & \multirow{2}{*}{ Units } & \multicolumn{5}{|c|}{ Value per 100 grams } \\
\hline & & Apple* & Pomegranate* $^{*}$ & Guava* & Papaya** $^{* *}$ & Plum* \\
\hline \multicolumn{7}{|l|}{ Macronutrients } \\
\hline Water & gram & 86.00 & 77.93 & 84.25 & 89.80 & 87.23 \\
\hline Total Fat & gram & 0.20 & 1.20 & 0.95 & 0.14 & 0.28 \\
\hline Protein & gram & 0.26 & 1.70 & 2.55 & 0.60 & 0.70 \\
\hline Total carbohydrate & gram & 13.81 & 19.00 & 14.32 & 10.98 & 11.42 \\
\hline Calories & kcal & 52.00 & 83.00 & 68.00 & 41.40 & 46.00 \\
\hline Dietary Fibers & gram & 2.40 & 14.00 & 5.40 & 0.80 & 1.40 \\
\hline Sugar & gram & 10.39 & 14.00 & 8.92 & 9.80 & 9.92 \\
\hline Ash & gram & 0.30 & 0.53 & 0.65 & 0.70 & 4.54 \\
\hline \multicolumn{7}{|l|}{ Micronutrients } \\
\hline \multicolumn{7}{|l|}{ Vitamin } \\
\hline Folate & $\mathrm{mcg}$ & 3.00 & 38.00 & 49.00 & 55.00 & 5.00 \\
\hline Niacin (Vit B3) & $\mathrm{mg}$ & 0.09 & 0.29 & 1.08 & 0.34 & 0.42 \\
\hline Riboflavin (Vit B2) & $\mathrm{mg}$ & 0.03 & 0.05 & 0.04 & 0.07 & 0.03 \\
\hline Thiamin (Vit B1) & $\mathrm{mg}$ & 0.02 & 0.07 & 0.07 & 0.05 & 0.03 \\
\hline Vitamin A & IU & 3.00 & 0.00 & 15.60 & 55.00 & 17.00 \\
\hline Vitamin B6 & $\mathrm{mg}$ & 0.04 & 0.08 & 0.11 & 0.15 & 0.03 \\
\hline Vitamin C & $\mathrm{mg}$ & 4.60 & 10.20 & 228.30 & 108.00 & 9.50 \\
\hline Vitamin $\mid E$ & $\mathrm{mg}$ & 0.18 & 0.60 & 0.73 & 5.30 & 0.26 \\
\hline Vitamin K & $\mathrm{mcg}$ & 2.20 & 16.40 & 2.60 & 2.90 & 6.40 \\
\hline \multicolumn{7}{|l|}{ Minerals } \\
\hline Calcium, $\mathrm{Ca}$ & $\mathrm{mg}$ & 6.00 & 10.00 & 18.00 & 24.00 & 6.00 \\
\hline Copper, $\mathrm{Cu}$ & $\mathrm{mg}$ & 0.03 & 0.16 & 0.23 & 0.14 & 0.06 \\
\hline Iron, Fe & $\mathrm{mg}$ & 0.12 & 0.30 & 0.26 & 0.66 & 0.17 \\
\hline Magnesium, $\mathrm{Mg}$ & $\mathrm{mg}$ & 5.00 & 12.00 & 22.00 & 33.00 & 7.00 \\
\hline Manganese, Mn & $\mathrm{mg}$ & 0.03 & 0.12 & 0.15 & 0.03 & 0.03 \\
\hline Phosphorus, $\mathrm{P}$ & $\mathrm{mg}$ & 11.00 & 36.00 & 40.00 & 33.00 & 16.00 \\
\hline Potassium, K & $\mathrm{mg}$ & 107.00 & 236.00 & 417.00 & 257.00 & 157.00 \\
\hline Selenium, Se & $\mathrm{mcg}$ & 0.00 & 0.50 & 0.60 & 1.50 & 0.00 \\
\hline Sodium, $\mathrm{Na}$ & $\mathrm{mg}$ & 1.00 & 3.00 & 2.00 & 3.00 & 0.00 \\
\hline Zinc, $\mathrm{Zn}$ & $\mathrm{mg}$ & 0.04 & 0.35 & 0.23 & 0.09 & 0.10 \\
\hline
\end{tabular}

Note: *USDA standard reference 2021 (https://www.nutritionvalue.org); **Ali et al. (2011)

\section{Discussion}

Coconut lorikeets are very active birds, so they require a large amount of a higher level of energy to maintain high metabolic rates (Gelis 2011). In the wild, the lorikeet primarily feeds on nectar as a source of carbohydrate and pollen as a source of protein (Gellis 2011). Dietary protein requirements of lorikeets are reported to be lower than those of similar-sized granivorous parrots (Frankel and Avram 2001). Poor nutrition is a common cause of many health problems in birds. They need a proper balance of carbohydrates, protein, vitamins, minerals, and water. In order for the lorikeets to stay healthy and reproduce in the colony aviary, a main diet of nectar substitutes should be provided along with a variety of vegetables and fruits to achieve a balanced diet. Vegetables and fruits are considered in dietary guidance because of their high concentrations of dietary fiber, vitamins, minerals, especially electrolytes; and more recently phytochemicals, especially antioxidants (Slavin and Lloyd 2012). There are many types of vegetables and fruits were available that we can find in the market, but in fact that not all types of vegetables and fruits that we offered to the coconut lorikeets will attract them. As we know that the highest expenses for keeping birds in captivity were the bird's diet. According to Cruz et al. (2016), the cost of feed is at least
$60 \%$ of the total cost. Therefore, information on the attractiveness of vegetables and fruits to the coconut lorikeets is very important to know as the basis of their feeds. This information is very useful for preparing a bird's healthy diet, which favoured by the coconut lorikeet to reduce feed waste and at the same time to reduce feed costs.

In the wild, the lorikeet learns which foods are safe to eat from their flock mates. The lorikeet has natural instinct to guide his food choices (Schaefer 2011). According to McKenzie and Whittingham (2010), birds have individual preferences for foods based on the taste, habits, food placement, texture, size, shape and colour. The results of experiment 1 in this study showed that the attractiveness of the vegetables and fruits were influenced by several factors such as shape, texture, size, and taste. An example was cauliflower and broccoli. Cauliflower resembles broccoli, but the broccoli more attracts birds than cauliflower. Cauliflower is white florets while broccoli is green florets. Besides their different colors, the bunched florets growing from the central stem have differences. Cauliflower tightly bunches florets while broccoli florets are more spread out. Raw broccoli is more crunchy than cauliflower. It seems that tightly clumped florets of cauliflower make this vegetable unattractive to birds. The texture of broccoli with loosely 
clumped florets is more easily for coconut lorikeet to nibble on it and take the tiny green buds of florets with their beak and a brush-tipped tongue. An example for the attractiveness of the fruits, this study showed that small fruits such as kersen, buni and berries were placed in feed cups do not attract the birds. Fruit traits, such as size and shape, nutritional value, and conspicuousness affect fruitbird interactions (Sobral et al. 2010). There are many ways to offer fruit as bird food and attract the bird. For small fruits may be better to offer the bird still in a bunch and tied to their perch of natural branch tree which available in colony aviary. Birds can taste sweet, sour, and bitter flavors, and they learn which of those tastes are the most suitable and nutritious food sources (Bachmanov and Beauchamp 2007; Gilardi and Toft 2012). Matson and Koutsos (2006) stated that tastes and specific appetites may sometimes drive feed consumption.

In the wild, the lorikeets are arboreal and often seen feeding high up in the canopy of Eucalyptus trees (Klarich 2012). They rarely come to the ground to feed (Klarich 2012), therefore in the aviary, the feed cups also should be placed at a high level to make them feel safe and enjoy their feed. According to McKenzie and Whittingham (2010), preferences for foods can be influenced by the feed placement. The results in experiment 2 showed that the feed intake of vegetables and fruits in the first level of feed cup placement were higher than the lower level of feed cup placement. The daily intake of vegetables in this study showed that vegetable soybean was higher than yardlong bean, green cabbage, red cabbage, and broccoli. Zhang et al. (2015) stated that vegetable soybean is one of only a handful of plant-based foods that contain all the essential amino acids and the best source of secondary metabolites. The vegetable soybean has sweet, nutty, and mild flavour seed. A combination of sucrose, ascorbic acid, glutamic acid, and alanine makes vegetable soybeans tasty ( $\mathrm{Li}$ et al. 2012). The coconut lorikeet also favoured yardlong bean, although the feed intake was lower than vegetable soybean. The yardlong bean has a chewy and crunchy texture. According to Perchuk et al. (2020), seeds of yardlong bean contained less sucrose and more raffinose than pods seeds. The role of raffinose as a fiber source potential promoting the colonization of bifidobacteria and lactobacillus in the lorikeet intestinal tract. This may have the benefit of inhibiting clostridial and other pathogenic infections (McDonald 2003). The basic phenolic compound groups, found in yardlong beans, are phenolic acids and flavonoids. Phenolic compounds are interesting as bioactive compounds possessing antioxidants (Corso et al. 2020). This study showed that the coconut lorikeets also eat green cabbage and red cabbage. Although the red cabbage has more nutrients than the green cabbage as seen in the crude fiber, vitamin $\mathrm{C}$ and provitamin A contents (Adelanwa and Medugu 2015), the feed intake of red cabbage was lower than green cabbage. Feed intake of broccoli was the lowest compare to the other selected vegetables. We should try to offer floret broccoli on the whole instead of on pieces. Broccoli is a vegetable that should be included in the coconut lorikeets' diet since broccoli can provide nutrients that are needed by lorikeets. Broccoli is rich in dietary fiber, minerals, vitamins, and antioxidants that have proven health benefits. Broccoli has been reported as one of the main sources of natural antioxidants i.e., phenolic compounds and vitamins and chemopreventive compounds, i.e., glucosinolates and their degradation products, isothiocyanates (Campas-Baypoli et al. 2009). Fresh broccoli is an exceptionally rich source of vitamin $\mathrm{C}$. Vitamin $\mathrm{C}$ is a powerful natural anti-oxidant and immune modulator (Owis 2015). Along with vegetables, fruits also should be included in the coconut lorikeets diet. Fruits contain mostly sugars and fibers, and have a high water content and low levels of protein and fat (Slavin and Lloyd 2012). The type of fruit, the ripeness of the fruit, texture, sweetness of the fruits will affect the feed intake of fruits. Besides sugars, the organic acids present in the fruits also influence their taste and consumption pattern (Kumar et al. 2018). The birds eat the flesh and also sip the juice. Different species and even different individuals of the same species can prefer different fruits (Willson 1994). Fresh fruit offers birds many nutritional benefits. This study showed that the feed intake of plums was higher than the apple, pomegranate, papaya, and guava. The mineral content of plums increase as fruits ripen. These substances determine the nutritive value and taste of plums (Ertekina et al. 2006). Plums have an abundance of bioactive compounds such as phenolic acids, anthocyanins, carotenoids, flavanols, organic acids, (e.g., citric and malic acids), fiber (pectin), tannins, aromatic substances, enzymes (Birwal et al. 2017). The selection of fruit by birds may be driven by factors other than colour, traits like nutritional contents and secondary compounds also influence bird food preference (Schaefer 2011). For example, birds may actually prefer anthocyanins because of their antioxidative properties (Schaefer et al. 2008). The feed intake of apple was lower than plum since apple has crispy texture while plum has a soft texture and the coconut lorikeet prefer soft fruits. Apple is a rich source of sugars, minerals, dietary fiber, and functional compounds such as ascorbic acid and phenolics (Bondonno et al. 2017). Sugars, organic acids, and phenolic compounds, the major compounds in apple, impart taste characteristics, such as flavour, bitterness, and astringency to the fruits (Mihailovic' et al. 2018). Apple showed a higher concentration of fructose as compared to sucrose and glucose (Kumar et al. 2018).

The type of fruits which the third favoured by the coconut lorikeet was pomegranate. In the pomegranate, the edible part is the fleshy layer (aril) around each seed. The coconut lorikeet enjoys the juicy arils. The pomegranate peel, comprises around $50 \%$ of the whole fruit, while the edible part consists of $10 \%$ seeds and $40 \%$ arils (Sreekumar et al. 2014). The arils, apart from water $(85 \%)$, contain sugars, pectin, organic acids, phenolics, and flavonoids principally anthocyanins (Viuda-Martos et al. 2010). According to Nge et al. (2015), the pomegranate is an antioxidant-rich fruit. The taste is governed mainly by the presence of sugars (glucose and fructose) and organic acids (primarily citric and malic acids). The aroma evolves from the presence of dozens of volatiles, including alcohols, aldehydes, ketones, and terpenes, which provide a 
mixture of various 'green', 'woody', 'earthy', 'fruity', 'floral', 'sweet' and 'musty' notes (Mayuoni-Kirshinbaum and Porat 2014). Daily feed intake of papaya was lower than plum, apple, and pomegranate but higher than guava. Papaya is a deliciously sweet fruit with musky undertones and a distinctive pleasant aroma. It has a soft texture with butter-like consistency (Bari et al. 2006). This study showed that the feed intake of plum higher than papaya instead of papaya has a soft texture almost the same as plum but has a different aroma and the sugar content of papaya is lower than plum. Papaya is rich in iron and calcium; a good source of vitamins $\mathrm{A}$ and an excellent source of vitamin C (ascorbic acid) (Vyas and Shah 2016). It contains relatively high levels of beta-carotene, which the body converts to vitamin A (Ali et al. 2011). The feed intake of guava is the lowest. According to Vora (2018) a very well-known nutritional benefit of the consumption of guava is its rich vitamin $\mathrm{C}$ content performing varied immune functions and protecting the body from free radicals. Apart from this, a high level of manganese, folate, and fiber have additional benefits that are associated with guava. Guava has high nutritional value and also has antioxidant, anti-diabetic, antibacterial, anti-diarrhoeal, anti-hypotensive, analgesic,and anti inflammatory, anticancer, anti-hypertensive, antifungal, and antipyretic properties (Uzzaman et al. 2018)

Coconut lorikeet is a specialist nectar bird (nectarivorous), therefore $87 \%$ (seasonally ranging from $68 \%$ to $100 \%$ ) of its diet consists of nectar and pollen with the remainder made up of fruits and leaf (Cannon 1982). According to Nicolson and Thornburg (2007), nectar in the wild besides being a source of carbohydrates also contains essential amino acids even though the protein content is low. Prijono and Rachmatika (2019) reported that two lorikeets were kept in the cage consumed $76.41 \%$ of their diet in the form of the brown sugar solution as an alternative source of carbohydrate, while the supplemented diet (seed, vegetables, and pellets) were consumed by the birds only $23.59 \%$. In this study, the six coconut lorikeets in the colony aviary were fed on siwalan sugar solution ( $20 \%$ concentration) added with a commercial baby biscuit as their main diet. According to Prijono and Rachmatika (2020), palm sugar such as siwalan sugar solution not only has low protein content similar to nectar, but also contains high energy and rich in nutrient (amino acids especially high in lysine, vitamin and mineral) as present in the sap from which it is derived. Since siwalan sugar solution as the primary diet has low protein content, therefore the siwalan sugar solution should be added other food as a protein source. Prijono and Rachmatika (2019) suggested that the commercial baby biscuit was chosen as an alternative for protein food since this biscuit has a sweet taste, contain $9 \%$ protein, rich in vitamin and minerals, also the birds like it. To achieve a balanced diet, besides the coconut lorikeets fed with siwalan sugar solution and added commercial baby biscuits, it is important to give the birds a variety of vegetables and fruits. A balanced diet is a diet that contains differing kinds of foods in certain quantities and proportions so that the requirement for macronutrients and micronutrients is adequate to maintain healthy and thrive. The result of this study showed that the coconut lorikeets were kept in colony aviary consumed $79.20 \%$ of their diet in the form of siwalan sugar solution as an alternative source of carbohydrate while vegetables and fruits were consumed $20.80 \%$. Although vegetables and fruits composition in coconut lorikeets diet only $20.80 \%$, they are a good source of carbohydrates, vitamins, and mineral and the birds need for their nutrient requirement. It was suggested that the coconut lorikeet should be fed more vegetables than fruits, since most of the energy requirement has been met from siwalan sugar solution as the main diet. It is better if the coconut lorikeet fed on different vegetables and fruits every day. At least the coconut lorikeet fed on three types of vegetables and two types of fruits in their diet.

Balanced nutrition as the proportionality of nutrients in the diet is important to the coconut lorikeets. Any nutritional imbalance can result in a host of disorders and diseases in the birds. Therefore is important to know the nutrition composition of each type of vegetable and fruit that will be lorikeet's diet, especially the iron. According to Gelis (2011) high iron content as found in foods used in lorikeet diets, combined with feeding foods high in vitamin $\mathrm{C}$ can lead to iron accumulation in various organs but particularly in the liver, and iron storage disease. In this study, the vegetable that high in iron is vegetable soybean $(2.27 \mathrm{mg} / 100 \mathrm{~g})$, while the fruit that is high in iron is papaya $(0.66 \mathrm{mg} / 100 \mathrm{~g})$. On their own, these foods do not cause iron storage disease, but given with food rich in vitamins $\mathrm{C}$, they can lead to excessive iron in the body. According to West et al. (2009) to the diet for lorikeets should contain less than $100 \mathrm{ppm}$ of iron (ppm= parts per million $=\mathrm{mg} / \mathrm{kg}$ ). Therefore vegetable soybean and papaya are still good and save for lorikeets although we should give vegetable soybean and papaya combine with other vegetables and fruits which content low vitamin $\mathrm{C}$. We are able to prevent iron storage disease by balancing the amount of iron and vitamins in the bird's diet.

\section{ACKNOWLEDGEMENTS}

We would like to thank the Research Center for Biology, National Research and Innovation Agency (BRIN) for financialassistance. We also thank Suwita (CV. Pasundan) for kindly lending us his coconut lorikeets, Suparno, Cece and Babay for keeping and caring the bird.

\section{REFERENCES}

Adelanwa EB, Medugu JM. 2015. Variation in the nutrient composition of red and green cabbage (Brassica oleracea) with respect to age at harvest. J Appl Agric Res 7: 183-189.

Ali A, Devarajan S, Waly MI, Essa MM, Rahman MS. 2011. Nutritional and medicinal values of papaya (Carica papaya L.). In: Esa MM, Manickavasagan A, Sukumar E (eds). Natural Products and their Active Compounds. Nova Science Publishers, New York.

Bari L, Hassan P, Absar N, Haque ME, Khuda MIIF, Pervin MM, Shahanaz K, Hossain MI. 2006. Nutritional analysis of two local varieties of papaya (Carica papaya L.) at different maturity stages. Pak J Bio Sci 9: 137-140. DOI: 10.3923/pjbs.2006.137.140 
Birnie-Gauvin K, Peiman KS, Raubenheimer D, Cooke SJ. 2017. Nutritional physiology and ecology of wildlife in a changing world. Conserv Physiol 5 (1): 1-18. DOI:10.1093/conphys/cox030

Birwal P, Deshmukh G, Saurabh SP. 2017. Plums: A brief introduction. J Food Nutr Popul Health 1 (1): 1-8.

Bondonno NP, Bondonno CP, Ward NC, Hodgson JM, Croft KD. 2017 The cardiovascular health benefits of apples: Whole fruits vs isolated compounds. Trends Food Sci Technol 69: 243-256. DOI: 10.1016/j.tifs.2017.04.012

Cabana F, Lee JG. 2019. Feeding cluster preferences in four genera of Lories and Lorikeets (Loriinae) that should be considered in the diet of nectarivorous psittacine species in captivity. J Anim Physiol a Anim Nutr 103 (1): 354-362. DOI: 10.1111/jpn.13012

Campas-Baypoli ON, Sanchez-Machado DI, Bueno-Solano C, Nunez Gastelum JA, Reyes-Moreno C, Lopez-Cervantes J. 2009 Biochemical composition and physicochemical properties of broccoli flours. Intl J Food Sci Nutr 60 (S4): 163-173. DOI: 10.1080/09637480802702015

Cannon CE. 1982. The diet of lorikeets Trichoglossus spp. in the QueenslandNew South Wales border region. Emu 84: 16-22. DOI 10.1071/MU9840016

CITES. 2017. Convention on International Trade in Endangered Species of Wild Fauna and Flora. Appendices I, II and III.valid from 2 January 2017. 69 p.

Corso M, Perreau F, Mouille G, Lepiniec L. 2020. Specialized phenolic compounds in seeds: Structures, functions, and regulations. Plant Sci 296: 110471. DOI: 10.1016/j.plantsci.2020.110471

Cruz CEF, Cerva C, Andretta I. 2016. Financial costs of conserving captive-bred wild birds. Zool Gart 85 (6): 354-362. DOI 10.1016/j.zoolgart.2016.08.003.

Ertekina C, Gozlekcib S, Kabasa O, Sonmezc S, Akinci I. 2006. Some physical, pomological and nutritional properties of two plum (Prunus domestica L.) cultivars. J Food Eng 75: 508-514. DOI: 10.1016/j.jfoodeng.2005.04.034

Frankel TL, Avram D. 2001. Protein requirement of rainbow lorikeet, Trichoglossus haematodus. Aust J Zool 49: 435-443. DOI: $10.1071 / \mathrm{ZO} 01005$

Gelis S. 2011. A review of the nutrition of lories and lorikeets. Proceedings of AVES International Parrot Convention.

Gilardi JD, Toft CA. 2012. Parrots eat nutritious foods despite toxins PLoS ONE 7 (6): e38293. DOI: 10.1371/ journal. pone.0038293

Klarich R. 2012. The Rainbow Lorikeet Trichoglossus haematodus moluccanus. TAFE NSW - Western Sydney Institute, Richmond College, NSW Australia

Kumar P, Sethi S, Sharma P, Singh RR, Saham S, Sharmam S, Verma VK, Kumar S, Sharma SK. 2018. Nutritional characterization of apple as a function of genotype. J Food Sci Technol 55 (7): 2729-2738. DOI: $10.1007 / \mathrm{s} 13197-018-3195-\mathrm{x}$

Li YS, Du M, Zhang QY, Wang GH, Hashemi M, Liu XB, 2012. Greater differences exist in seed protein, oil, total soluble sugar and sucrose content of vegetable soybean genotypes [Glycine $\max (\mathrm{L}$.$) Merrill] in$ Northeast China. Aust J Crop Sci 6 (12): 1681-1686. DOI: $10.13140 / 2.1 .2841 .2163$

Madhu, Kochhar A. 2014. Proximate composition, available carbohydrates, dietary fibre and anti- nutritional factors of broccoli (Brassica oleracea L var. Italica plenck) leaf and floret powder. Biosci Disc 5 (1): 45-49.

Martin P, Bateson P. 1986. Measuring Behaviour. Cambridge University Press, Cambridge.

Matson KD, Koutsos EA. 2006. Captive parrot nutrition: Interactions with anatomy, physiology, and behavior. In: Luescher AU (eds). Manual of Parrot Behavior. Blackwell Publishing, Oxford.

Mayuoni-Kirshinbaum L, Porat R. 2014. The flavor of pomegranate fruit: A review. J Sci Food Agric 94 (1): 21-27. DOI: 10.1002/isfa.6311

McDonald D. 2003. Feeding ecology and nutrition of Australian lorikeets. Semin Avian Exotic Pet Med 12 (4): 195-204. DOI: 10.1053.S1055 937X(03)00035-5
McKenzie AJ, Whittingham MJ. 2010. Birds select conventional over organic wheat when given free choice. J Sci Food Agric 90: 18611869. DOI: $10.1002 /$ jsfa. 4025

Mihailovic'NR, Mihailovic'VB, Kreft S, Ciric'AR, Joksovic'LG, Đurdevic' PT. 2018. Analysis of phenolics in the peel and pulp of wild apples (Malus sylvestris (L.) Mill.). J Food Compost Anal 67: 1-9. DOI: $10.1016 /$ j.jfca.2017.11.007

Nge ST, Martosupono M, Karwur FF. 2015. The polyphenolics and health effects of pomegranate. Sains Medika 6 (1): 30-39. DOI: 10.26532/sainsmed.v6i1.342

Nicolson SW, Thornburg RW. 2007. Nectar chemistry. In: Nicolson SW, Nepi M, Pacini E (eds). Nectaries and Nectar. Springer, Dordrecht. DOI: $10.1007 / 978-1-4020-5937-7$

Owis AI. 2015. Broccoli; The green beauty: A review. J Pharm Sci Res 7 (9): 696-703.

Pem D, Jeewon R. 2015. Fruit and vegetable intake: Benefits and progress of nutrition education interventions- narrative Review article. Iran J Public Health 44 (10): 1309-1321

Perchuk I, Shelenga T, Gurkina M, Miroshnichenko E, Burlyaeva M. 2020. Composition of primary and secondary metabolite compounds in seeds and pods of asparagus bean (Vigna unguiculata (L.) Walp.) from China. Molecules 25 (3778): 1-16. DOI: 10.3390/molecules25173778

Prijono SN, Rachmatika R. 2019. Potency of brown sugar as a nectar substitute for Trichoglossus haematodus in captivity. Biosaintifika 11 (2): 186-193. DOI: 10.15294/ biosaintifika.v11i2.18730

Prijono SN, Rachmatika R. 2020. Effect of sweetness level and amino acid composition of palm sugar on feed intake of Trichoglossus haematodus in captivity. Biosaintifika 12 (2): 254-261. DOI: 10.15294/biosaintifika.v12i2.24458

Schaefer HM, McGraw K, Catoni C. 2008. Birds use fruit colour as honest signal of dietary antioxidant rewards. Funct Ecol 22: 303-310. DOI: $10.1111 /$ j.1365-2435.2007.01363.x

Schaefer HM. 2011. Why fruits go to the dark side. Acta Oecol 37: 604610. DOI: $10.1016 /$ j.actao.2011.04.008

Slavin JL, Lloyd B. 2012. Health benefits of fruits and vegetables. Adv Nutr 3: 506-516. DOI: 10.3945/an.112.002154.

Sobral M, Larrinaga AR, Guitian J. 2010. Fruit-size preferences in wild and native Eurasian blackbirds (Turdus Merula) feeding on Oneseed Hawthorn (Crataegus Monogyna). Auk 127: 532-539. DOI: 10.1525/auk.2010.09079

Sreekumar S, Sithul H, Muraleedharan P, Azeez JM, Sreeharshan S. 2014. Pomegranate fruit as a rich source of biologically active compounds. Biomed Res Int 2014 (25): 686921. DOI: $10.1155 / 2014 / 686921$.

USDA standard reference. 2021. https://www.nutritionvalue.org [Accessed 23 May 2021]

Uzzaman S, Akanda KM, Mehjabin S, Parvez GMM. 2018. A short review on a nutritional fruit : Guava. Open Access Toxicol Res 1 (1): $1-8$.

Viuda-Martos M, Fernández-López J, Pérez-Álvarez JA. 2010. Pomegranate and its many functional components as related to human health: A review. Compr Rev Food Sci Food Saf 9: 635-654. DOI: 10.1111/j.1541-4337.2010.00131.x

Vora JD. 2018. Biochemical and nutritional assessment of guava (Psidium guajava). IOSR J Biotechnol Biochem (IOSR-JBB) 4 (5): 1-7. DOI: 10.9790/264X-0405010107

Vyas MB, Shah SK. 2016. Review on nutritional and medicinal values of "Carica papaya". J Pharmacogn Phytochem 5 (4): 284-286

West GD, Garner MM, Talcott PA. 2009. Hemochromatosis in several species of lories with high dietary iron. J Avian Med Surg. DOI: 1647/1082-6742(2001)015[0297: HISSOL]2.0.C0;2

Willson MF. 1994. Fruit choice by captive American Robins. Condor 96: 494-502. DOI: 10.2307/1369331

Zhang QY, Li YS, Liu XB. 2015. Edible quality and its regulation in vegetable soybean (Glycine max (L.) Merr.). ASA, CSSA, SSSA International Annual Meetings Nov. 15-18, Minneapolis, MN. 